\title{
Crystallochemical Characterization of Magnetic Spinels prepared from Aqueous Solution
}

\author{
Stephen Mann, * Nicholas H. C. Sparks, Suzanne B. Couling \\ and Miranda C. Larcombe \\ School of Chemistry, University of Bath, Bath BA2 7AY \\ Richard B. Frankel \\ Physics Department, California Polytechnic State University, San Luis Obispo, \\ CA 93407, USA
}

\begin{abstract}
The crystallochemical characterization of magnetic spinels prepared from aqueous solution has been studied primarily by electron microscopy and ${ }^{57} \mathrm{Fe}$ Mössbauer spectroscopy. Two synthetic routes have been investigated: method 1; partial oxidation of $\mathrm{Fe}^{\mathrm{II}}$ solutions in the presence of $\mathrm{NO}_{3}^{-}$at $100^{\circ} \mathrm{C}$, and method 2; reaction of hydrated $\mathrm{Fe}^{\mathrm{III}}$ oxide (ferrihydrite) with $\mathrm{Fe}^{\mathrm{II}}$ ions at room temperature, $\mathrm{pH}=7,8$ and 9 . Both routes gave small (10-60 $\mathrm{nm})$ irregular magnetite $\left(\mathrm{Fe}_{3} \mathrm{O}_{4}\right)$ particles that were readily oxidised to maghemite $\left(\gamma-\mathrm{Fe}_{2} \mathrm{O}_{3}\right)$. The reaction proceeded via a green-rust intermediate and anions such as inorganic phosphate $\left(\mathrm{P}_{\mathrm{i}}\right)$ and $\mathrm{SO}_{4}{ }^{2-}$ reduced the rate of transformation. Spinel formation at room temperature was severely inhibited by $P_{i}$ levels of $1 \mathrm{~mol} \%$, whereas $20-30 \mathrm{~mol} \% \mathrm{P}_{\mathrm{i}}$ was required for retardation of crystallization at $100{ }^{\circ} \mathrm{C}$. Intermediate levels $(5-10 \mathrm{~mol} \%)$ resulted in morphological enhancement of the octahedral crystal habit. A similar effect was observed in the presence of $\mathrm{SO}_{4}^{2-}$ and at neutral $\mathrm{pH}$ in method 2.
\end{abstract}

The current interest in advanced materials is primarily directed towards the synthesis of novel solids. However, a further important aspect of this initiative is the crystallochemical tailoring of known substances with the aim of achieving functional specificity in solid-state applications. In this respect, we are involved in the elucidation of processes which modulate the crystallochemical properties of known magnetic materials. Ultimately, our objective is to synthesise structurally well defined magnetic spinels with homogeneous particle sizes and unique crystal morphologies as these properties are important in determining the catalytic and magnetic use of these materials.

Magnetite $\left(\mathrm{Fe}_{3} \mathrm{O}_{4}\right)$ has a cubic inverse spinel structure (space group, $F d 3 m, a=8.396$ $\AA$ ) with half of the $\mathrm{Fe}^{\mathrm{III}}$ ions in tetrahedral sites and both $\mathrm{Fe}^{\mathrm{II}}$ and $\mathrm{Fe}^{\mathrm{III}}$ cations randomly distributed in octahedral sites at temperatures above $119 \mathrm{~K}$. The structure is related to the fully oxidised compound, maghemite $\left(\gamma-\mathrm{Fe}_{2} \mathrm{O}_{3}\right)$ which can be considered as an iron-deficient spinel of variable structure ranging from disordered cubic symmetry $\left(a=8.34 \AA\right.$ ) to a tetragonal unit cell with ordered vacancies (space group, $P 4_{1} 2_{1}, a=$ $8.34 \AA, c=25.02 \AA)$. Conventional synthesis of magnetite, either by partial reduction of hematite $\left(\alpha-\mathrm{Fe}_{2} \mathrm{O}_{3}\right)$ or oxidation of Fe metal, is undertaken at high temperature (often $800{ }^{\circ} \mathrm{C}$ ). Since these reactions occur under severe environmental conditions, the potential for crystallographic design of the products is limited. A more promising synthetic route for controlled crystallization is from the aqueous phase. ${ }^{1}$

Here we report the characterization of magnetic spinels prepared by two independent methods based first on the partial oxidation of $\mathrm{Fe}^{\mathrm{II}}$ in the presence of $\mathrm{NO}_{3}^{-}$at $100^{\circ} \mathrm{C}^{2}$ and 
secondly, on the reaction of hydrated $\mathrm{Fe}^{\mathrm{III}}$ oxide (ferrihydrite) with $\mathrm{Fe}^{\mathrm{II}}$ ions at room temperature. ${ }^{3}$ Other routes from aqueous media at elevated temperature ${ }^{4-6}$ and room temperature ${ }^{5,7-10}$ have been reported. Our objectives have been to investigate: (i) the influence of low molecular weight additives such as inorganic phosphate $\left(\mathrm{P}_{\mathrm{i}}\right)$ on spinel formation, and (ii) the potential for spinel growth at room temperature and neutral $\mathrm{pH}$. Preliminary studies of the former have been reported. ${ }^{11}$ The latter route offers the possibility of using a wide range of hydrophilic organic molecules (amino acids, peptides, proteins) or coordinating ligands that can be chemically tailored to induce a high degree of crystallochemical specificity in the products. In this respect, we note that biological magnetites are synthesized at ambient temperature and close to neutral $\mathrm{pH}$ with uniform particle sizes and novel species-specific morphologies. ${ }^{12,13}$

\section{Experimental}

\section{Preparation of Magnetic Spinels}

\section{Method 1. Partial Oxidation of Aqueous $\mathrm{Fe}^{\mathrm{II}}$ by $\mathrm{NO}_{3}^{-}$at $100^{\circ} \mathrm{C}$}

Magnetite was prepared under $\mathrm{N}_{2}$ at $100^{\circ} \mathrm{C}$ by the slow addition $\left(\mathrm{ca} .0 .5 \mathrm{~cm}^{3} \mathrm{~min}^{-1}\right)$ of a solution containing $0.1 \mathrm{~mol} \mathrm{KOH}$ and $0.008 \mathrm{~mol} \mathrm{KNO}_{3}$ dissolved in $30 \mathrm{~cm}^{3}$ of deoxygenated distilled water to $70 \mathrm{~cm}^{3}$ of a boiling deoxygenated solution containing $\mathrm{FeCl}_{2} \cdot 4 \mathrm{H}_{2} \mathrm{O}\left(0.514 \mathrm{~mol} \mathrm{dm}^{-3}\right)$ at $\mathrm{ca} . \mathrm{pH} 2.5$. A green gelatinous precipitate was immediately formed which turned dark blue and then black on continued addition of the alkaline mixture. The suspension was boiled for a further $30 \mathrm{~min}$ and allowed to cool. The resulting black precipitate was washed several times with distilled water followed by two washings with acetone and left to dry at room temperature. Samples were removed at ten minute intervals during the course of the reaction, centrifuged, and the supernatent analysed for total dissolved $\mathrm{Fe}$ (by atomic absorption spectroscopy) and the $\mathrm{pH}$ measured. The $\mathrm{Fe}^{\mathrm{III}}: \mathrm{Fe}^{\mathrm{II}}$ ratio in the final product was calculated as follows. $\mathrm{Fe}^{\mathrm{II}}$ concentration was determined by dissolving a known weight of the spinel in conc. $\mathrm{HCl}$ acid under $\mathrm{N}_{2}$ and titrating against deoxygenated $\mathrm{K}_{2} \mathrm{Cr}_{2} \mathrm{O}_{7}$, total $\mathrm{Fe}$ was determined by atomic absorption spectroscopy, and $\mathrm{Fe}^{\mathrm{III}}$ was calculated from the difference between total $\mathrm{Fe}$ and $\mathrm{Fe}^{\mathrm{II}}$ concentrations.

The above synthesis was repeated with the following modifications; $(a) \mathrm{FeSO}_{4} \cdot 7 \mathrm{H}_{2} \mathrm{O}$ in place of $\mathrm{FeCl}_{2} \cdot 4 \mathrm{H}_{2} \mathrm{O}$ and $(b)$ in the presence of 5, 10, 15, 20 and $30 \mathrm{~mol} \% \mathrm{KH}_{2} \mathrm{PO}_{4}$ added to the $\mathrm{Fe}^{\mathrm{II}}$ solution prior to $\mathrm{OH}^{-} / \mathrm{NO}_{3}^{-}$addition.

\section{Method 2. Room-temperature Transformation of Hydrated $\mathrm{Fe}^{\mathrm{III}}$ Oxide (Ferrihydrite) in the Presence of $\mathrm{Fe}^{\mathrm{II}}$ Ions}

Ferrihydrite was prepared by the addition of deoxygenated $\mathrm{NaOH}$ to $100 \mathrm{~cm}^{3}$ of a 19.6 mmol dm ${ }^{-3}$ deoxygenated solution of $\mathrm{Fe}\left(\mathrm{NO}_{3}\right)_{3} \cdot 9 \mathrm{H}_{2} \mathrm{O}$. The resulting brown suspension was purged with $\mathrm{N}_{2}$ overnight. $100 \mathrm{~cm}^{3}$ of a deoxygenated solution of $19.6 \mathrm{mmol} \mathrm{dm} \mathrm{m}^{-3}$ $\mathrm{FeSO}_{4} \cdot 7 \mathrm{H}_{2} \mathrm{O}$ was added to the stirred suspension under $\mathrm{N}_{2}$ and the $\mathrm{pH}$ adjusted to a value of $7.0,8.0$ or 9.0 depending on the experiment. The reaction was accompanied by an immediate darkening of the ferrihydrite suspension and a continual decrease in $\mathrm{pH}$ which was buffered by the addition of deoxygenated $\mathrm{NaOH}$ such that the $\mathrm{pH}$ was kept within 0.2 units of the starting value. All experiments were run at room temperature under a stream of $\mathrm{N}_{2}$ gas until no further change in $\mathrm{pH}$ was noted (3-26 h depending on the starting $\mathrm{pH}$ ). The resulting black precipitate was collected by centrifugation, washed with deoxygenated distilled water followed by deoxygenated acetate buffer $(\mathrm{pH} 4.1$, $0.5 \mathrm{~mol} \mathrm{dm}^{-3}$ ) to remove any residual $\mathrm{Fe}^{\mathrm{II}}$ ions. Further washings with deoxygenated water and finally deoxygenated acetone were undertaken and the precipitate left to dry at room temperature under $\mathrm{N}_{2}$. 
The above procedure was modified at a reaction $\mathrm{pH}$ of 8.0 to include the presence of 1 and $5 \mathrm{~mol} \%$ deoxygenated $\mathrm{NaH}_{2} \mathrm{PO}_{4} \cdot 2 \mathrm{H}_{2} \mathrm{O}$ added to the ferrihydrite suspension prior to $\mathrm{Fe}^{\mathrm{II}}$ addition.

\section{Characterization of Products}

\section{Electron Microscopy}

Samples for transmission electron microscopy were prepared by placing a droplet of the reaction suspension onto carbon-coated, nitrocellulose-covered copper electron microscope grids followed by blotting on filter paper and air drying. Changes in the crystallochemical properties of the precipitates formed during the phase transformation of hydrated ferric oxide (method 2 above) were determined by removing small aliquots of the suspension at different time intervals and mounting the material on electron microscope grids as above. Electron diffraction patterns were recorded on populations of particles and single crystals imaged in the selected area mode of the electron microscope. Compositional data on individual crystals as well as aggregates of particles were obtained using energy dispersive X-ray analysis (e.d.X) facilities coupled to the electron microscope. For conventional work a Jeol 100CX analytical transmission electron microscope operating at $100 \mathrm{keV}$ was used. Lattice imaging studies were undertaken on individual crystallites using a Jeol 2000FX transmission electron microscope operated at $200 \mathrm{keV}$ and capable of a point-to-point resolution of $0.28 \mathrm{~nm}$.

\section{X-Ray Diffraction, Infrared and ${ }^{57} \mathrm{Fe}$ Mössbauer Spectroscopy and Magnetic Measurements}

Samples of the dried powders were examined by X-ray diffraction using a DebyeScherrer camera and FeK $\alpha$ radiation. Infrared spectra were recorded on a Perkin-Elmer 597 spectrometer. ${ }^{57} \mathrm{Fe}$ Mössbauer spectra were recorded at variable temperature using a constant acceleration spectrometer with a ${ }^{57} \mathrm{Co}(\mathrm{Rh})$ source. Temperatures between 1.5 and $300 \mathrm{~K}$ were maintained and measured with a calibrated $\mathrm{Si}$ diode and a Lakeshore Cryotronics temperature controller. Spectra were analysed by a least-squares fitting program. Magnetic measurements were made with an S.H.E. Squid magnetometer.

\section{Results}

\section{Method 1}

\section{(a) In the Absence of Phosphate}

Fig. $1(a)$ shows the changes in $\mathrm{pH}$ and total dissolved Fe concentration accompanying the partial oxidation of a $\mathrm{FeCl}_{2}$ solution in the presence of $\mathrm{NO}_{3}^{-}$at $100{ }^{\circ} \mathrm{C}$. Addition of the $\mathrm{OH}^{-} / \mathrm{NO}_{3}^{-}$solution resulted in an initial rapid rise in $\mathrm{pH}$ with the dissolved $\mathrm{Fe}$ concentration remaining almost constant. After $10 \mathrm{~min}$, the $\mathrm{pH}$ increase was reduced on continual addition of the alkali mixture although the Fe concentration decreased rapidly. Complete removal of soluble Fe after 50 min was accompanied by a rapid rise in $\mathrm{pH}$ and a black precipitate which showed a positive magnetic response to a small bar magnet. Chemical determination of the $\mathrm{Fe}^{\mathrm{II}}: \mathrm{Fe}^{\mathrm{III}}$ ratio in the product gave a value of $1: 3$ and $\mathrm{X}$-ray diffraction data identified the material as a mixture of $\mathrm{Fe}_{3} \mathrm{O}_{4}$ and $\gamma-\mathrm{Fe}_{2} \mathrm{O}_{3}$ spinels (table 1). These results were consistent with the Mössbauer spectrum of the sample recorded at $298 \mathrm{~K}$ [fig. 2(a)] which showed two overlapping subspectra corresponding to spinel-type tetrahedral $\mathrm{Fe}^{\mathrm{III}}$ and octahedral $\mathrm{Fe}^{\mathrm{III}}$ and $\mathrm{Fe}^{\mathrm{II}}$ sites (table 2). The intensity of the averaged $\left(\mathrm{Fe}^{\mathrm{II}}+\mathrm{Fe}^{\mathrm{III}}\right)$ subspectrum was significantly reduced from that observed for stoichiometric magnetite ${ }^{14}$ indicating substantial oxidation of $\mathrm{Fe}^{\mathrm{II}}$ ions in the octahedral sites. Magnetic moment measurements were also significantly smaller than 

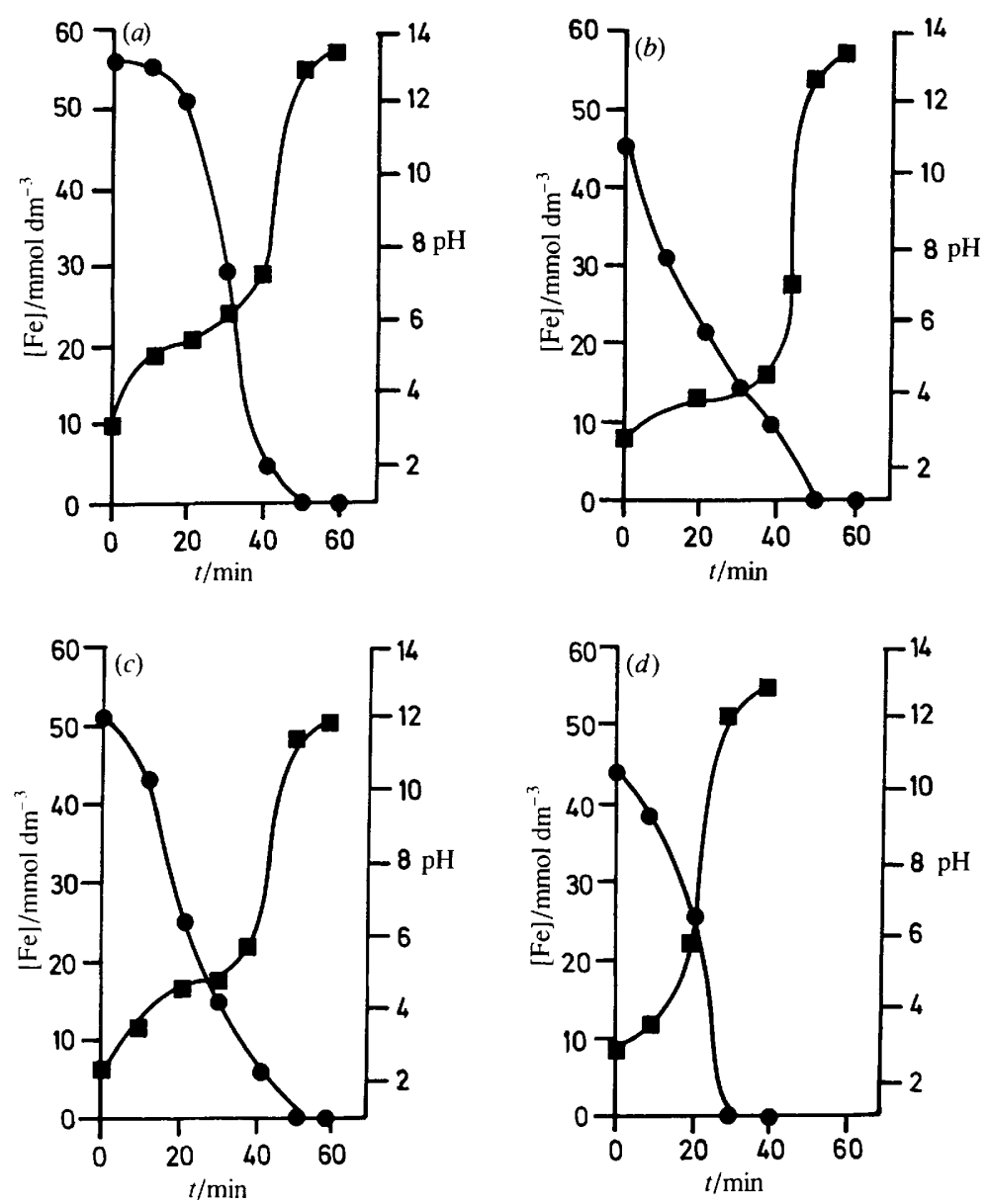

Fig. 1. Changes in soluble $\mathrm{Fe}$ concentration $\left(\mathrm{mmol} \mathrm{dm}^{-3}\right)(\boldsymbol{O})$, and $\mathrm{pH}(\boldsymbol{\square})$, during the reaction of aqueous $\mathrm{Fe}^{\mathrm{II}}$ with $\mathrm{NO}_{3}^{-} ;(a) \mathrm{FeCl}_{2}$ solution; $(b) \mathrm{FeSO}_{4}$ solution; $(c) \mathrm{FeCl}_{2}$ with $10 \mathrm{~mol} \% \mathrm{P}_{\mathrm{i}}$, (d) $\mathrm{FeCl}_{2}$ with $20 \mathrm{~mol} \% \mathrm{P}_{i}$.

those of stoichiometric magnetite (table 2). However, infrared spectra showed only two bands at 570 and $360 \mathrm{~cm}^{-1}$ [fig. $3(a)$ ] characteristic of $\mathrm{Fe}_{3} \mathrm{O}_{4}{ }^{15}$ indicating that the bulk structure of the sample was primarily magnetite. This suggests that the maghemite phase was probably confined to an oxidised surface layer around the magnetite particles.

Electron microscopic examination of the sample showed irregularly shaped particles in the size range 20-60 nm [plate 1(a)]. E.d.X. analysis detected Fe and K (trace) (table 3) and powder electron diffraction patterns were consistent with the $\mathrm{X}$-ray diffraction data.

Magnetic spinels prepared from $\mathrm{Fe}^{\mathrm{II}}$ sulphate solutions were shown to be $\mathrm{Fe}_{3} \mathrm{O}_{4}$ with some surface $\gamma-\mathrm{Fe}_{2} \mathrm{O}_{3}$ on the basis of X.r.d., infrared spectroscopy and chemical analysis $\left(\mathrm{Fe}^{\mathrm{III}} / \mathrm{Fe}^{\mathrm{II}}=2.9\right)$ (Mössbauer data were not available). The $\mathrm{pH}$ and dissolved $\mathrm{Fe}^{\mathrm{II}}$ profiles were similar to those for $\mathrm{Fe}^{\mathrm{II}}$ chloride [fig. 1(b)]. Electron microscopy showed that the spinel crystals formed from $\mathrm{Fe}^{\mathrm{II}}$ sulphate solution were generally larger, often up to $150 \mathrm{~nm}$ in length, and the particles exhibited a well defined cubo-octahedral morphology [plate $1(b)$ ] in contrast to the irregular crystals formed from the oxidation of $\mathrm{Fe}^{11}$ chloride solution [plate $1(a)$ ]. 

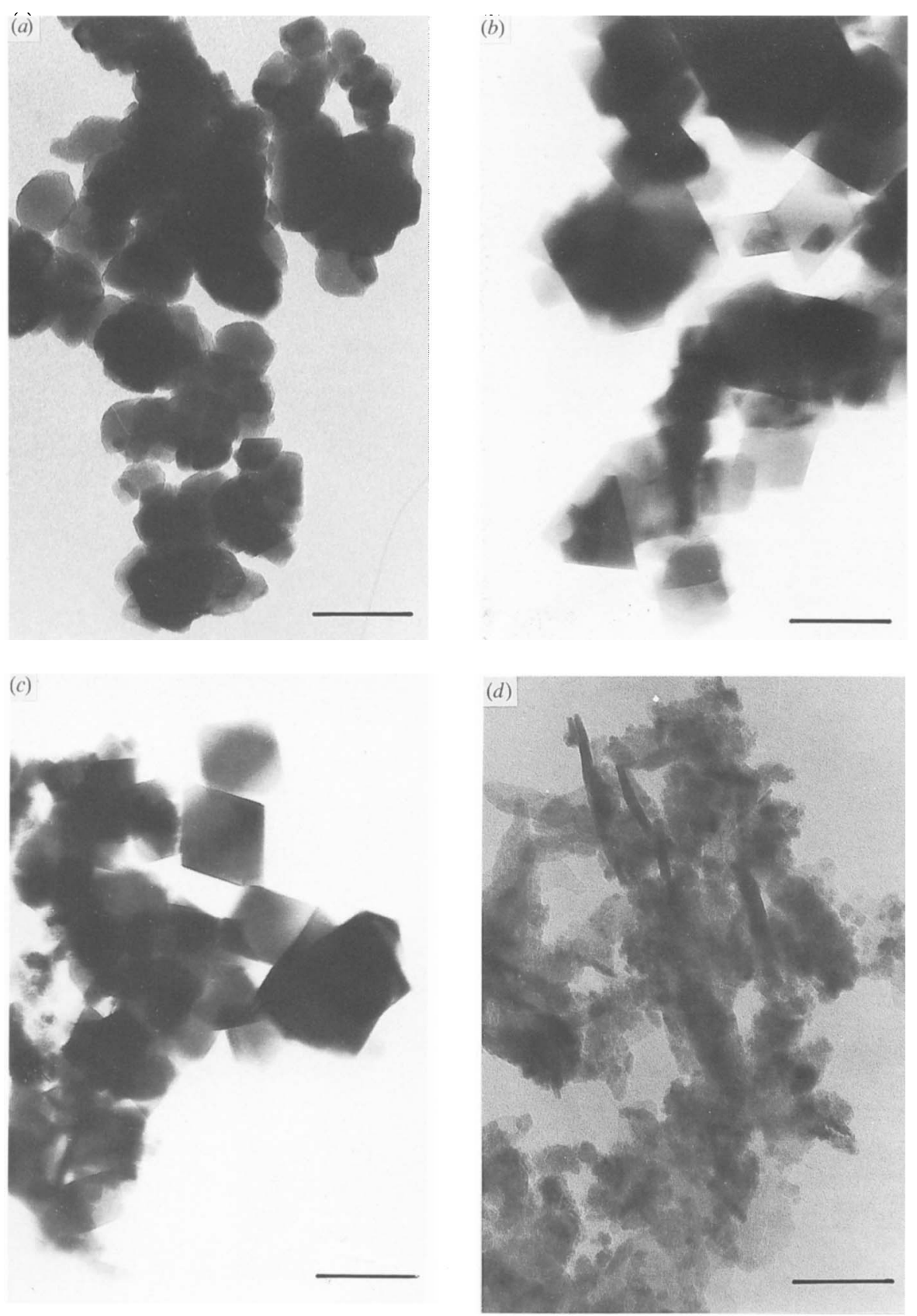

Plate 1. Transmission electron micrographs of spinel products from partial oxidation of $\mathrm{Fe}^{11}$

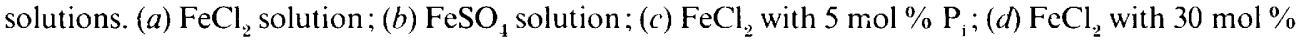
$\mathrm{P}_{\mathrm{i}}$. Needle-like particles in $(d)$ are $\alpha-\mathrm{FeOOH}$. Scale bar in all micrographs is $100 \mathrm{~nm}$. 

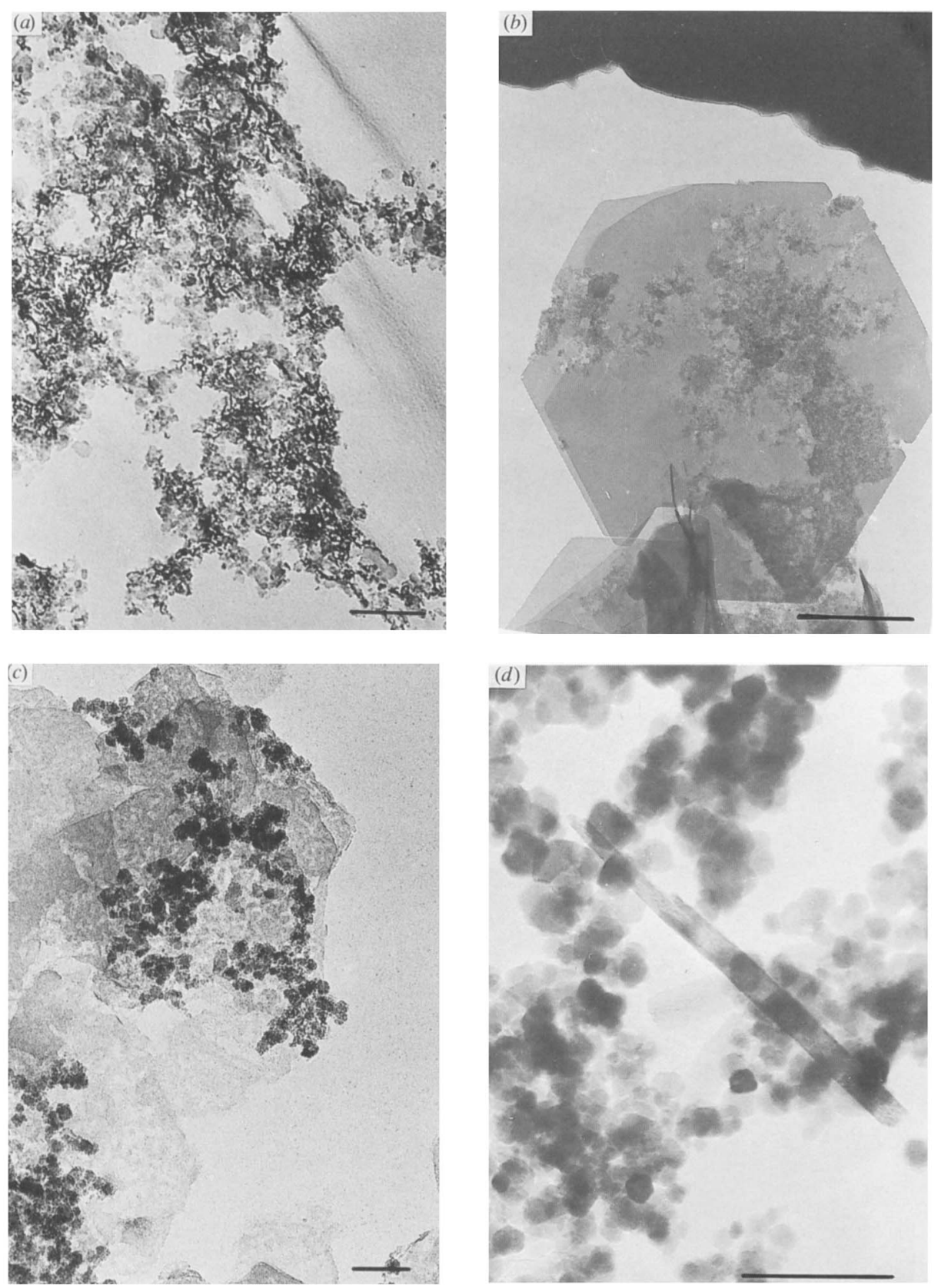

Plate 2. Transmission electron micrographs of precipitates from reaction of ferrihydrite with aqueous $\mathrm{Fe}^{\mathrm{II}} ;(a)$ unreacted ferrihydrite, $\mathrm{pH} 8,30 \mathrm{~min} ;(b)$ green rust, $\mathrm{pH} 8$ (or 9), $30 \mathrm{~min} ;(c)$ green rust and $\mathrm{Fe}_{3} \mathrm{O}_{4}, \mathrm{pH} 8,60$ min and (d) magnetite (the needle-like crystal is $\alpha-\mathrm{FeOOH}$ ), $\mathrm{pH}$ $8,22 \mathrm{~h}$. Scale bars: $(a)$ and $(b) 500 \mathrm{~nm} ;(c)$ and $(d) 100 \mathrm{~nm}$. 

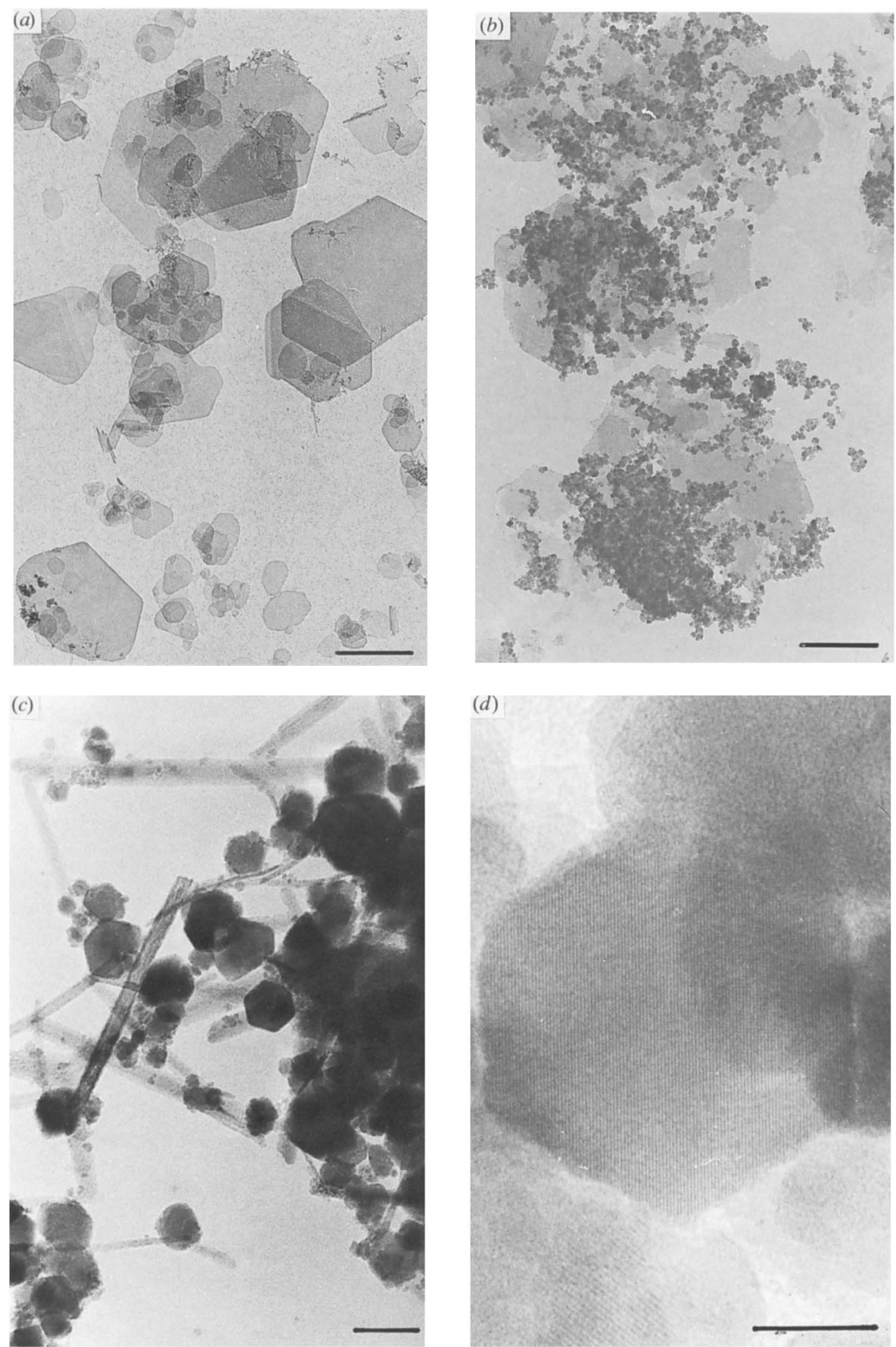

Plate 3. Precipitates formed from the reaction of ferrihydrite with aqueous $\mathrm{Fe}^{\mathrm{II}}$ at $\mathrm{pH} 7 ;(a)$ green rust, $2 \mathrm{~h} ;(b)$ green rust and $\mathrm{Fe}_{3} \mathrm{O}_{4}, 3 \mathrm{~h} ;(c) \mathrm{Fe}_{3} \mathrm{O}_{4}$ and needle-like $\alpha$ - $\mathrm{FeOOH}$ and $(d)$ lattice image of a $\mathrm{Fe}_{3} \mathrm{O}_{4}$ single crystal showing $\{200\}(4.2 \AA)$ fringes and well defined cubo-octahedral crystal edges. Scale bars: $(a)$ and $(b) 500 \mathrm{~nm} ;(c) 50 \mathrm{~nm}$ and $(d) 10 \mathrm{~nm}$. 

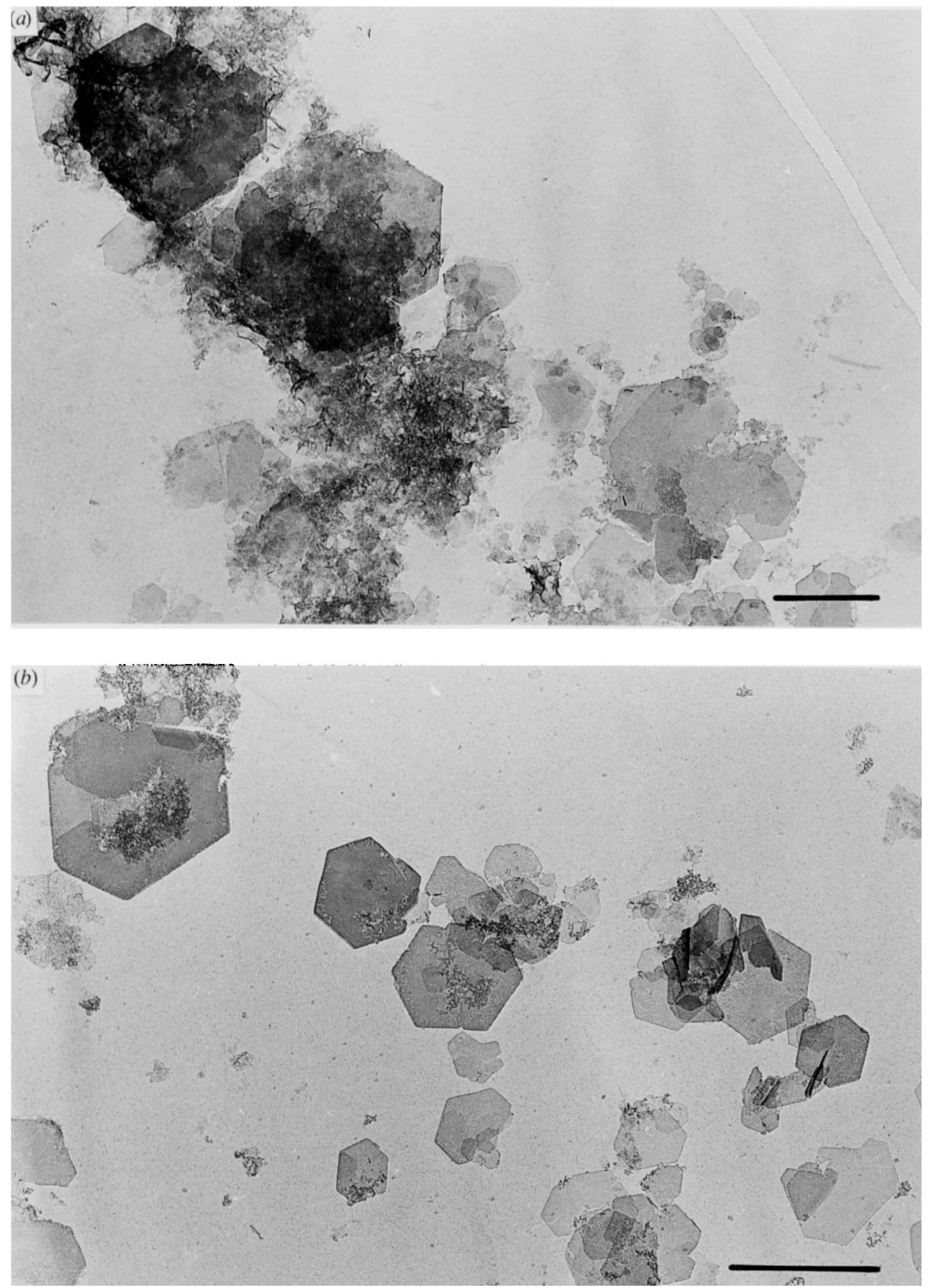

Plate 4. Precipitates formed from the reaction of ferrihydrite with aqueous $\mathrm{Fe}^{\mathrm{II}}$ at $\mathrm{pH} 8$ in the presence of $5 \mathrm{~mol} \% \mathrm{P}_{\mathrm{i}} ;(a)$ unreacted ferrihydrite and green rust, $4 \mathrm{~h} ;(b)$ green rust and trace amounts of ferrihydrite, $50 \mathrm{~h}$. Scale bars: (a) $500 \mathrm{~nm}$ and (b) $1 \mu \mathrm{m}$. 
Table 1. Representative X-ray diffraction data ( $d$-spacings/ $\AA$ ) for spinel products ${ }^{a}$

\begin{tabular}{|c|c|c|}
\hline \multicolumn{3}{|c|}{$d$-spacing $/ \AA$} \\
\hline$\gamma-\mathrm{Fe}_{2} \mathrm{O}_{3}{ }^{b}$ & $\mathrm{Fe}_{3} \mathrm{O}_{4}{ }^{\mathrm{C}}$ & product \\
\hline 4.82 & 4.85 & 4.84 \\
\hline 4.18 & -- & 4.18 \\
\hline 3.20 & - & 3.26 \\
\hline 2.95 & 2.97 & 2.96 \\
\hline 2.78 & - & 2.78 \\
\hline 2.514 & 2.532 & 2.525 \\
\hline 2.408 & - & 2.416 \\
\hline 2.086 & 2.100 & 2.090 \\
\hline 1.701 & 1.714 & 1.708 \\
\hline 1.604 & 1.617 & 1.614 \\
\hline 1.474 & 1.485 & 1.479 \\
\hline 1.318 & 1.327 & 1.324 \\
\hline 1.272 & 1.280 & 1.277 \\
\hline 1.258 & 1.266 & 1.263 \\
\hline 1.204 & 1.212 & 1.209 \\
\hline 1.115 & 1.122 & 1.119 \\
\hline 1.086 & 1.093 & 1.090 \\
\hline 1.043 & 1.050 & 1.047 \\
\hline
\end{tabular}

${ }^{a}$ All samples gave similar diffraction spacings but the number of $\gamma-\mathrm{Fe}_{2} \mathrm{O}_{3}$ lines varied in different experiments depending on the extent of air oxidation of the materials.

${ }^{b}$ X.r.d. File 15-1402, ${ }^{c}$ X.r.d. File 19-629.

\section{(b) In the Presence of Inorganic Phosphate}

Addition of 5-30 mol \% $\mathrm{KH}_{2} \mathrm{PO}_{4}\left(\mathrm{P}_{\mathrm{i}}\right)$ to $\mathrm{Fe}^{\mathrm{II}}$ chloride solutions prior to $\mathrm{OH}^{-} / \mathrm{NO}_{3}^{-}$ addition resulted in structural and morphological changes in the spinel products. X.r.d. patterns, infrared spectra [fig. 3(b)], room temperature Mössbauer spectra [fig. 2(b) and $(c)$; table 2] and magnetic measurements (table 2) of crystals grown in the presence of $5 \%$ and $10 \% \mathrm{P}_{\mathrm{i}}$ showed that the samples comprised surface oxidised $\mathrm{Fe}_{3} \mathrm{O}_{4}$ similar to that formed in the undoped system. The infrared spectra showed an additional band at $950 \mathrm{~cm}^{-1}$ [figure $3(b)$ ] corresponding to the $\mathrm{P}-\mathrm{O}-\mathrm{Fe}$ symmetric stretch. ${ }^{16}$ Particles examined by e.d.X analysis showed that some $\mathrm{P}_{\mathrm{i}}$ was closely associated with the spinel crystals (table 3). The $\mathrm{pH}$ and dissolved $\mathrm{Fe}^{\mathrm{II}}$ profiles [fig. 1(c)] were essentially unchanged from the non-phosphate containing systems. The crystals were $50-100 \mathrm{~nm}$ in size and had a well defined cubo-octahedral morphology [plate 1(c)]. These results are similar to those described above for spinel formation from $\mathrm{Fe}^{\mathrm{II}}$ sulphate solutions and indicate the importance of anion charge in determining the crystallochemical nature of the magnetic products.

Increasing the $\mathrm{P}_{\mathrm{i}}$ concentration to $20-30 \mathrm{~mol} \%$ resulted in marked changes in the structural and magnetic properties of the oxidation product. Addition of $\mathrm{NO}_{3}^{-} / \mathrm{OH}^{-}$first gave a dark blue-green product which turned dark brown towards the end of the reaction. The Fe concentration and $\mathrm{pH}$ profiles [fig. $1(d)$ ] showed a more rapid uptake of Fe from solution and a continual rise in $\mathrm{pH}$ throughout the reaction. X.r.d. patterns of the samples gave weak broad lines with $d$-spacings corresponding to $\mathrm{Fe}_{3} \mathrm{O}_{4} / \gamma$ - $\mathrm{Fe}_{2} \mathrm{O}_{3}$ indicating that the spinels were of low structural order. The degradation of structural 


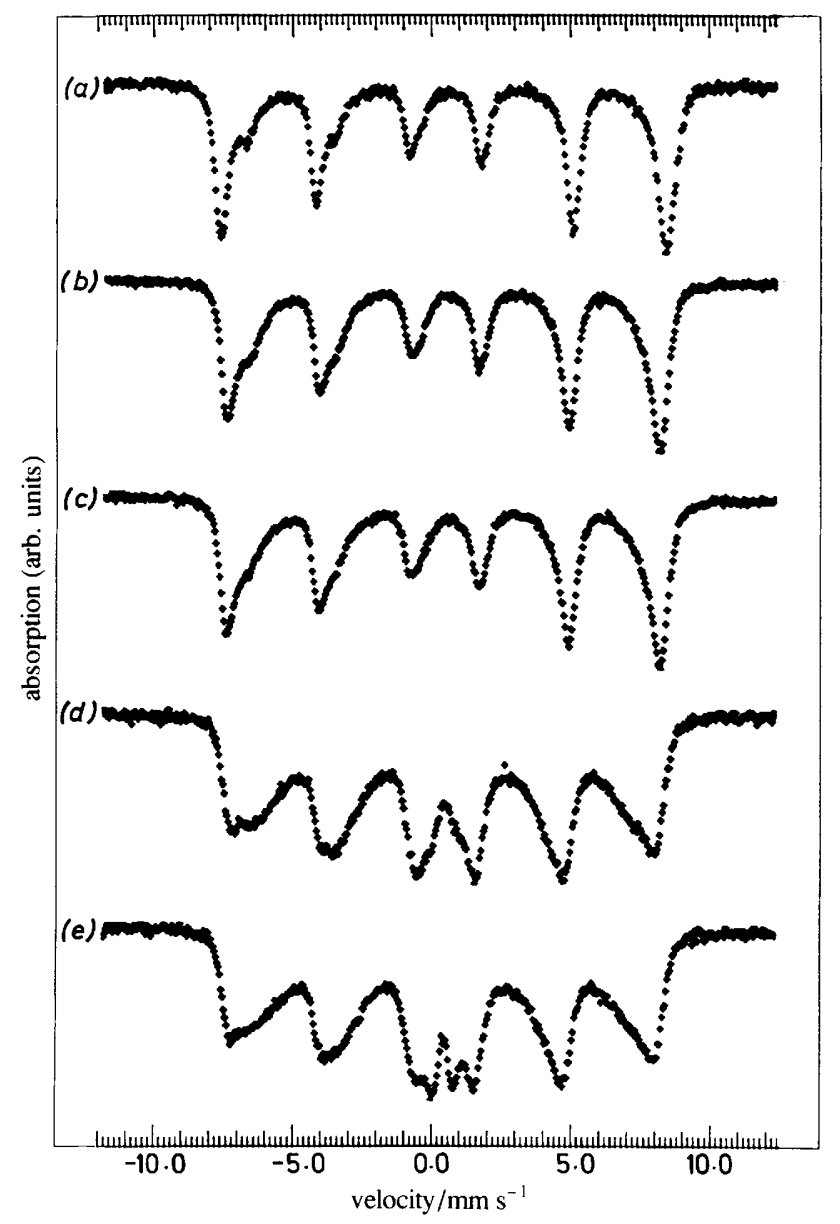

Fig. 2. ${ }^{57} \mathrm{Fe}$ Mössbauer spectra of samples from partial oxidation of $\mathrm{FeCl}_{2}$ solutions; $(a) 0 ;(b) 5$; (c) $10 ;(d) 20$ and (e) $30 \mathrm{~mol} \% \mathrm{P}_{1}$. Spectra were recorded at $298 \mathrm{~K}$.

order was also apparent in the marked reduction in the saturation magnetic moment (table 2) and in the Mössbauer spectra [fig. 1 $(d)$ and (e)] which showed that, although magnetic ordering was still present at $298 \mathrm{~K}$, the lines were extensively broadened. Furthermore, the $30 \mathrm{~mol} \% \mathrm{P}_{\mathrm{i}}$ product showed evidence of a weak high-spin $\mathrm{Fe}^{\mathrm{III}}$ quadrupole doublet in the central region of the spectrum. Since no diffraction lines were observed for non-spinel crystalline iron oxides, this spectral component possibly corresponds to an amorphous or poorly crystalline $\mathrm{Fe}^{\mathrm{III}}$ oxide of small particle size, for example, ferrihydrite. Infrared spectra of the samples showed only weak $\mathrm{Fe}_{3} \mathrm{O}_{4}$ bands and a strong $\mathrm{P}_{\mathrm{i}}$ band at $950 \mathrm{~cm}^{-1}$ [fig. 3(c)], consistent with the above results. Electron micrographs showed that whereas the particles formed in the presence of $20 \mathrm{~mol} \% \mathrm{P}_{\mathrm{i}}$ were 40-120 nm octahedral crystals, those prepared in $30 \mathrm{~mol} \% \mathrm{P}_{\mathrm{i}}$ comprised ill defined grains of much lower size $(10-40 \mathrm{~nm})$ [plate $1(d)$ ] E.d.X analysis showed $P_{i}$ closely associated with all the particles (table 3$)$. Some needle-like particles ( $100 \mathrm{~nm}$ in length) of goethite $(\alpha-\mathrm{FeOOH})$ were also occasionally observed in both samples [plate $1(d)$ ] although this material was not detected by X.r.d. 
Table 2. ${ }^{57} \mathrm{Fe}$ Mössbauer parameters

\begin{tabular}{|c|c|c|c|c|c|}
\hline sample & $T / \mathrm{K}$ & $\delta / \mathrm{mm} \mathrm{s}^{-1 a}$ & $\Delta / \mathrm{mm} \mathrm{s}^{-1 b}$ & $\mathrm{HF} / \mathrm{kOe}^{c}$ & $\mathrm{MM} / \mathrm{emu} \mathrm{g}^{-1 d}$ \\
\hline \multicolumn{6}{|c|}{ method 1} \\
\hline $0 \mathrm{~mol} \% \mathrm{P}_{\mathrm{i}}$ & 298 & 0.34 & - & $49072 \%$ & 76.5 \\
\hline & - & 0.58 & - & $45028 \%$ & - \\
\hline $5 \mathrm{~mol} \% \mathrm{P}_{i}$ & 298 & 0.34 & - & $48554 \%$ & 76.8 \\
\hline - & - & 0.55 & - & $44546 \%$ & - \\
\hline $10 \mathrm{~mol} \% \mathrm{P}_{\mathrm{i}}$ & 298 & 0.33 & - & $48556 \%$ & 74.2 \\
\hline & - & 0.55 & - & $42244 \%$ & - \\
\hline $20 \mathrm{~mol} \% \mathrm{P}_{\mathrm{i}}$ & - & -- & 一 & $-\quad-$ & 42.6 \\
\hline $30 \mathrm{~mol} \% \mathbf{P}_{\mathrm{i}}$ & - & - & - & $-\quad-$ & 42.6 \\
\hline \multicolumn{6}{|c|}{ method 2} \\
\hline pH 9 & 298 & 0.39 & - & $502-$ & - \\
\hline pH 8 & 298 & 0.39 & - & $503-$ & - \\
\hline $\mathrm{pH} 7$ & 298 & 0.38 & - & $503-$ & - \\
\hline - & - & 0.42 & - & $450-$ & - \\
\hline $\mathrm{pH} 8$ & 200 & 0.42 & 0.81 & $-82 \%$ & - \\
\hline $1 \mathrm{~mol} \% P_{i}$ & - & 0.39 & - & $470 \quad 18 \%$ & - \\
\hline $\mathrm{pH} 8$ & 80 & 0.47 & 0.80 & $-\quad-$ & - \\
\hline $5 \mathrm{~mol} \% \mathrm{P}_{\mathrm{i}}$ & 8 & 0.47 & - & $482-$ & - \\
\hline
\end{tabular}

${ }^{a} \delta$, Isomer shift. ${ }^{b} \Delta$, quadrupole splitting. ${ }^{C} \mathrm{HF}$, magnetic hyperfine field. ${ }^{d}$, MM, saturation magnetic moment per gram; for comparison, stoichiometric $\mathrm{Fe}_{3} \mathrm{O}_{4}$ and $\gamma-\mathrm{Fe}_{2} \mathrm{O}_{3}$ have values of 92.0 and 56.0 emu $\mathrm{g}^{-1}$, respectively.

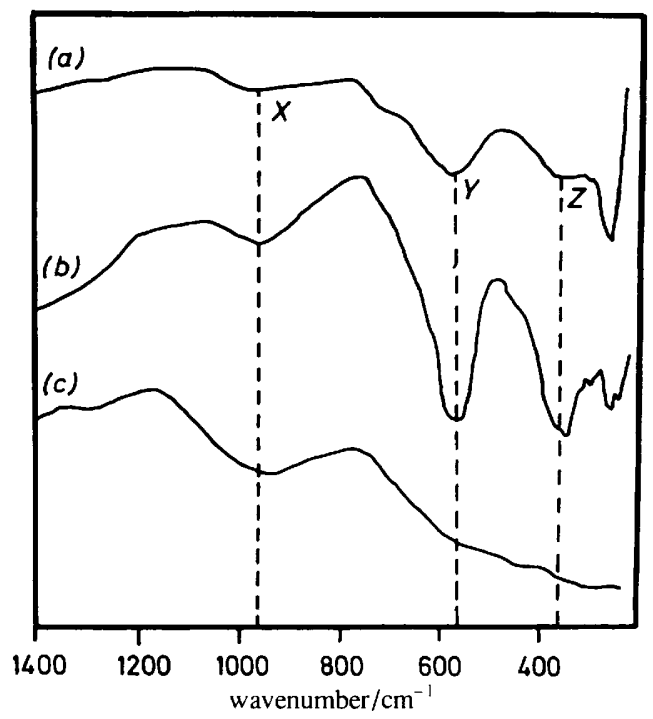

Fig. 3. Infrared spectra of samples from partial oxidation of $\mathrm{FeCl}_{2}$ solutions; $(a) 0 ;(b) 10$ and (c) $30 \mathrm{~mol} \% \mathrm{P}_{\mathrm{i}}$. Peak $X, v(\mathrm{FeO}-\mathrm{P})$; peaks $Y$ and $Z, v(\mathrm{FeO}-\mathrm{Fe})$.

\section{Method 2}

Reaction of ferrihydrite at room temperature in the presence of $\mathrm{Fe}^{\mathrm{Il}}$ at $\mathrm{pH} 9$ gave a magnetic product after $3 \mathrm{~h}$ which was identified as a mixture of $\mathrm{Fe}_{3} \mathrm{O}_{4}$ and $\gamma-\mathrm{Fe}_{2} \mathrm{O}_{3}$ by X.r.d. and electron diffraction. Mössbauer spectra showed only a single hyperfine sextet [fig. 4(a), table 2] indicating that the major component was $\gamma-\mathrm{Fe}_{2} \mathrm{O}_{3}$. The corresponding 
Table 3. E.d.X. analysis data (wt \% element) for spinel samples prepared by method 1

\begin{tabular}{lcrrrr}
\hline & \multicolumn{5}{c}{ dopant level/atom \% $\mathbf{P}_{\mathrm{i}}{ }^{a}$} \\
\cline { 2 - 6 } element & \multicolumn{1}{c}{0} & \multicolumn{1}{c}{5} & \multicolumn{1}{c}{10} & \multicolumn{1}{c}{20} & \multicolumn{1}{c}{30} \\
\hline $\mathrm{Fe}$ & 67.53 & 70.29 & 66.33 & 70.26 & 67.73 \\
$\mathrm{O}$ & 25.15 & 26.85 & 25.33 & 26.17 & 25.22 \\
$\mathrm{P}$ & - & 0.95 & 2.08 & 1.14 & 2.06 \\
\hline
\end{tabular}

${ }^{a} \mathrm{Al}$ (sample holder), $\mathrm{Si}$ (silicone grease) and $\mathrm{K}$ (residual $\mathrm{KOH} / \mathrm{KNO}_{3}$ ) were also present in trace amounts giving a total wt $\%$ of 100 for each sample.

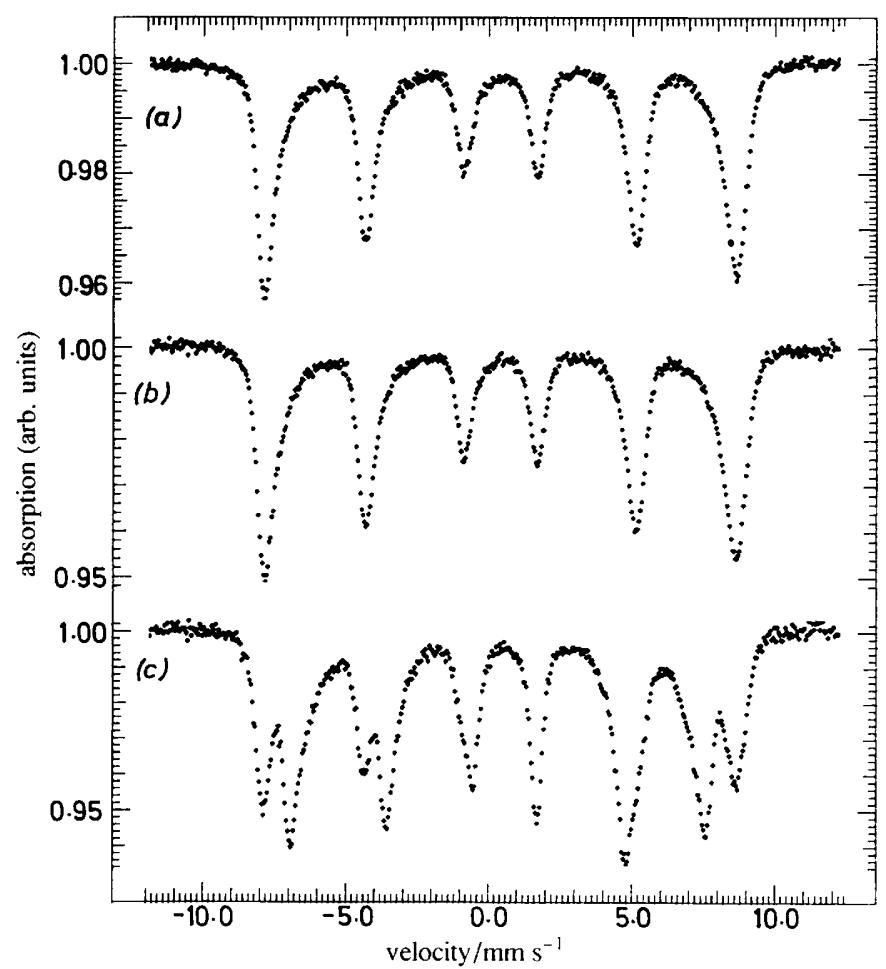

Fig. 4. ${ }^{57} \mathrm{Fe}$ Mössbauer spectra of samples from the reaction of ferrihydrite and aqueous $\mathrm{Fe}^{11}$ at room temperature and at $(a) \mathrm{pH} 9 ;(b) \mathrm{pH} 8 ;(c) \mathrm{pH} 7$. Spectra were recorded at $298 \mathrm{~K}$.

reaction at $\mathrm{pH} 8$ was slower and a magnetic product was isolated after 12 h. X.r.d. data from a freshly prepared sample gave reflections corresponding to $\mathrm{Fe}_{3} \mathrm{O}_{4}$ although the dried sample rapidly oxidised in air to $\gamma-\mathrm{Fe}_{2} \mathrm{O}_{3}$ as shown by the Mössbauer spectrum [fig. $5(b)]$.

Changes in the crystallochemical properties of the reaction intermediates and spinel products were followed by electron microscopy. At both $\mathrm{pH}$ values the reaction proceeded via a pseudo-hexagonal plate-like precursor [plate $2(b)$ ] that gave singlecrystal electron diffraction patterns corresponding to a poorly-crystalline green rust $\mathrm{II}^{17}$ [ $d$-spacings; $2.66(101)$ and $1.52 \AA$ (112)]. Whereas green rust (mean size ca. $450 \mathrm{~nm}$ ) was predominant in samples taken after $30 \mathrm{~min}$ at $\mathrm{pH}$, corresponding samples from the $\mathrm{pH} 8$ 

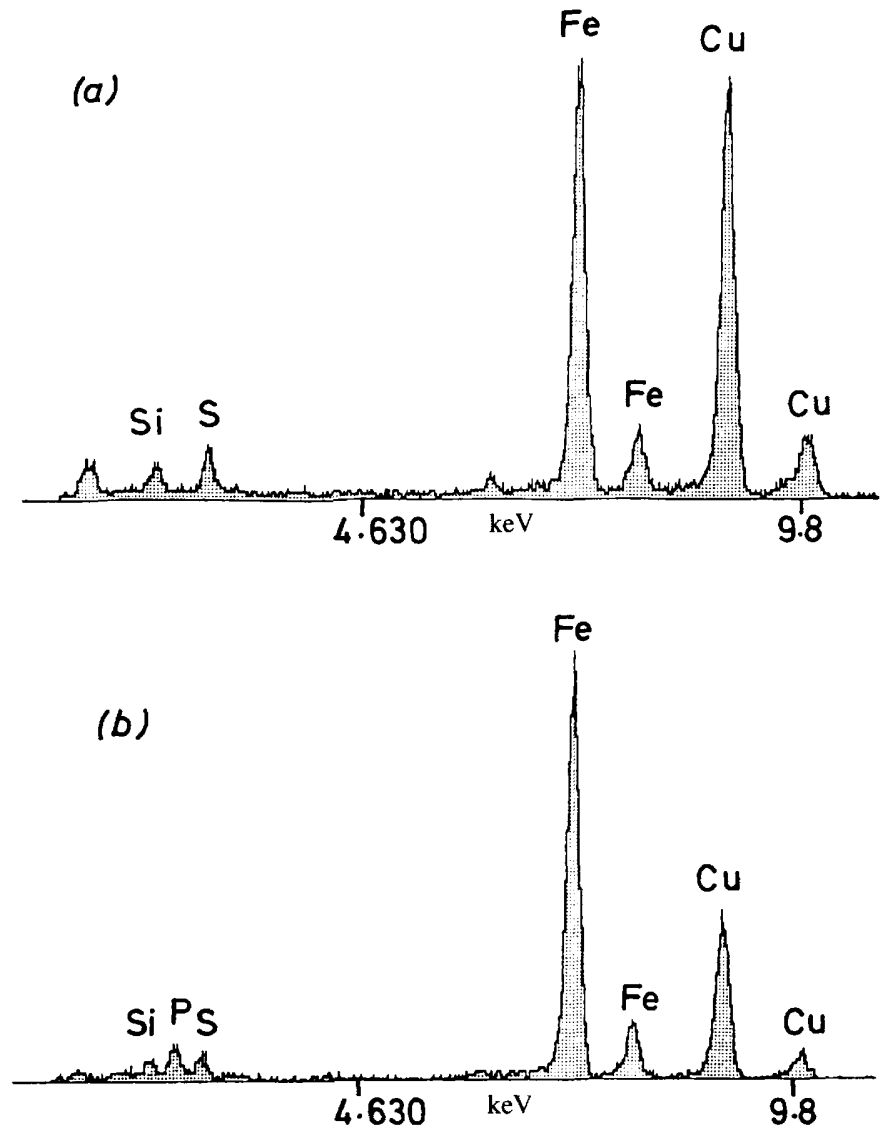

Fig. 5. E.d.X. spectra of green rust prepared at $\mathrm{pH} 8$ from the reaction of ferrihydrite and aqueous $\mathrm{Fe}^{\mathrm{II}} ;(a) 0$ and $(b) 5 \mathrm{~mol} \% \mathrm{P}_{\mathrm{i}}$. Cu peaks originate from the sample holder and $\mathrm{Si}$ is a contaminant (from silicone grease).

system contained much of the unreacted starting material [plate 2(a)]. Subsequent transformation of green rust to magnetite appeared to take place at the surface of the intermediate and was associated with a concomitant corrosion of the pseudo-hexagonal platelets [plate 2(c)]. The magnetic crystals were irregular in shape during the early stages of the transformation but an octahedral or cubo-octahedral morphology was apparent in the mature crystals [plate $2(d)$ ]. Particle size distributions and mean diameters for spinel crystals at different stages of growth were similar indicating that ripening of the early crystals was not a predominant mechanism of formation. Furthermore, the mean diameter, range and standard deviation $(32,10-60$ and $9.5 \mathrm{~nm}$, respectively, at $\mathrm{pH} 9$ ) of the spinel crystals were not significantly different in the two systems even though the reaction was substantially slower at $\mathrm{pH} 8$. Similar values were also obtained from particles grown at $\mathrm{pH} 7$ (see below). This suggests that the particle size of the magnetic products is independent of the rate of formation and is possibly constrained by other factors such as the local supersaturation levels and structural disorder in the growing crystals.

E.d.X. spectra showed the presence of $\mathrm{S}$ [from $\mathrm{Fe}^{\mathrm{II}}$ sulphate] in both the ferrihydrite and green rust materials [fig. 5(a)]. No $\mathrm{S}$ was observed in the corresponding analysis of the spinel crystals.

The above reaction, when carried out at $\mathrm{pH} 7$, resulted in a mixture of magnetic and 


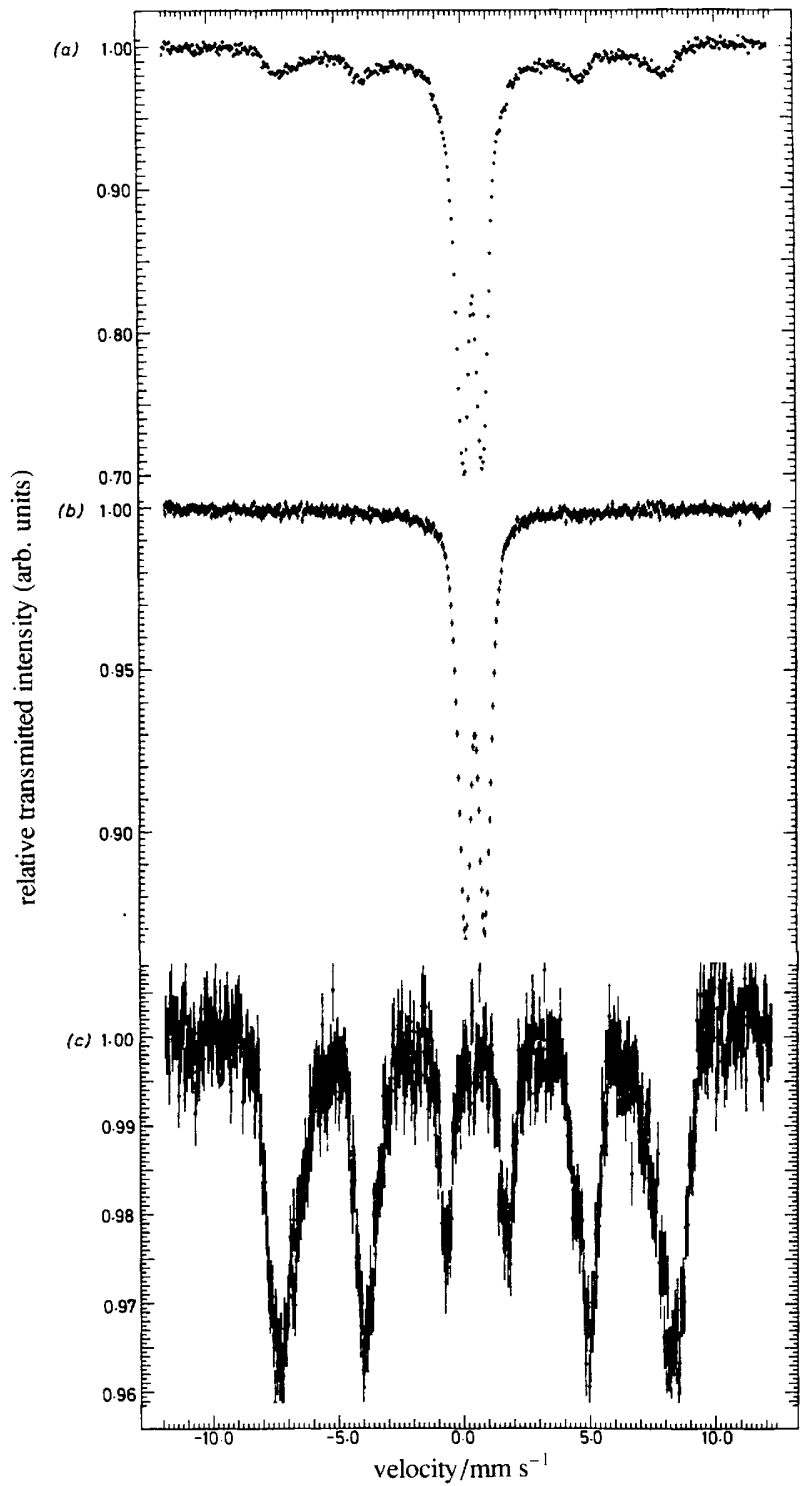

Fig. 6. ${ }^{57} \mathrm{Fe}$ Mössbauer spectra of samples from the reaction of ferrihydrite and aqueous $\mathrm{Fe}^{\mathrm{II}}$ at room temperature, $\mathrm{pH} 8$; (a) $1 \mathrm{~mol} \% \mathrm{P}_{\mathrm{i}} 200 \mathrm{~K}$; (b) $5 \mathrm{~mol} \% \mathrm{P}_{\mathrm{i}}, 80 \mathrm{~K}$ and $(c) 5 \mathrm{~mol} \% \mathrm{P}_{\mathrm{i}}, 8 \mathrm{~K}$.

non-magnetic oxides. Green rust was formed during the first $2 \mathrm{~h}$ of the reaction followed by slow transformation ( $26 \mathrm{~h}$ to completion) to $\mathrm{Fe}_{3} \mathrm{O}_{4} / \gamma-\mathrm{Fe}_{2} \mathrm{O}_{3}$ and $\alpha-\mathrm{FeOOH}$ (goethite) (plate 3). Mössbauer spectra were consistent with the diffraction data and showed hyperfine split components corresponding to $\gamma-\mathrm{Fe}_{2} \mathrm{O}_{3}$ and $\alpha$-FeOOH [fig. 4(c), table 2]. Whereas the $\mathrm{Fe}_{3} \mathrm{O}_{4}$ particles formed in close proximity to the green rust platelets [plate $3(c)$ ], the $\alpha-\mathrm{FeOOH}$ needle-like crystals were spatially separated. The spinel crystals had a size range $10-60 \mathrm{~nm}$ and mean diameter of $33 \mathrm{~nm}$, which were not significantly different from spinels formed at higher $\mathrm{pH}$ values. There appeared, however, to be an increased morphological resolution when compared to the higher $\mathrm{pH}$ products, with many crystals exhibiting a well defined cubo-octahedral habit [plate 3(c)]. High- 
resolution electron micrographs showed lattice fringes running continuously and coherently across the total width of the individual spinel particles [plate $3(d)$ ]. These results indicated that the spinel particles are well ordered single-domain crystallites.

Addition of $1-5 \mathrm{~mol} \% \mathrm{P}_{\mathrm{i}}$ prior to $\mathrm{Fe}^{\mathrm{II}}$ addition to ferrihydrite inhibited spinel formation. The rate of green rust formation was significantly reduced and although green rust was present after $4 \mathrm{~h}$, unreacted ferrihydrite was present throughout the reaction (plate 4). The initial green rust particles were irregular and associated with an amorphous gel of ferrihydrite [plate $4(a)$ ]. At $50 \mathrm{~h}$, well developed pseudo-hexagonal plate-like crystals were observed [plate $4(b)$ ]. No spinel phases were detected by X.r.d. or electron diffraction. E.d.X spectra of both the ferrihydrite and green rust particles showed the presence of $\mathrm{P}$ and $\mathrm{S}$ (from sulphate) in these solids (fig. 5).

Mössbauer spectra of the above samples showed no evidence of spinel phases. The spectra recorded at $200 \mathrm{~K}$ consisted of a high-spin $\mathrm{Fe}^{\mathrm{lII}}$ quadrupole doublet [fig. 6(a), table 2]. A minor component, corresponding to a hyperfine split sextet, was also observed in the sample prepared in the presence of $1 \mathrm{~mol} \% \mathrm{P}_{\mathrm{i}}$ [fig. 6(a)]. A similar component was only observed at temperatures below $80 \mathrm{~K}$ in the sample prepared in the presence of $5 \mathrm{~mol} \% \mathrm{P}_{\mathrm{i}}$ [fig. $6(b)$ and $(c)$, table 2]. Lowering the temperature to $8 \mathrm{~K}$ resulted in the loss of the central doublet and the concomitant increase in the sextet component. The relatively low hyperfine field value (table 2) and the broad lines of the sextet suggest that the material is not $\gamma-\mathrm{Fe}_{2} \mathrm{O}_{3}$ of small particle size. On the basis of the electron microscopy results, the spectral data can be interpreted as arising from a mixture of disordered $\mathrm{Fe}^{\mathrm{III}}$ oxides, possibly formed by air oxidation of green rust in combination with unreacted ferrihydrite. The temperature dependence of the spectra is therefore characteristic of magnetically ordered small particles $(<10 \mathrm{~nm})$ exhibiting superparamagnetism.

\section{General Comments}

The results presented in this paper show that magnetic spinels can be formed from aqueous media and that the crystallochemical properties of these materials are readily influenced by changes in $\mathrm{pH}$, temperature and anionic species present in the reaction. Although $\mathrm{Fe}_{3} \mathrm{O}_{4}$ is the initial product formed by partial oxidation of $\mathrm{Fe}^{\mathrm{II}}$ at $100{ }^{\circ} \mathrm{C}$ and by the reaction of ferrihydrite with $\mathrm{Fe}^{\mathrm{II}}$ at room temperature, the material formed in the latter system rapidly oxidises to $\gamma-\mathrm{Fe}_{2} \mathrm{O}_{3}$ during sample isolation and storage. Since the particle sizes were similar in both systems, the low temperature product is possibly more disordered. Both synthetic routes involved green rust intermediates which are hydrated mixed valence compounds, ${ }^{17}$ and the subsequent dehydration and transformation to $\mathrm{Fe}_{3} \mathrm{O}_{4}$ will be favoured at higher temperature. Furthermore, the high final $\mathrm{pH}$ of method 1 compared with the lower buffered $\mathrm{pH}$ values of method 2, favours the formation of oxo- rather than oxy-bridges in the product.

Although we have been successful in preparing spinels at ambient temperature and neutral $\mathrm{pH}$, we have not attained the degree of specificity characteristic of the biologically controlled synthesis of stoichiometric magnetite, as found, for example, in magnetotactic bacteria. ${ }^{13,18}$ Future work will focus on achieving greater chemical control over spinel formation through the use of gel media and micellar compartments which may limit the rate of reaction and provide increased regulation of nucleation and crystal growth.

Since ferrihydrite has been shown to be a precursor to magnetite formation in bacteria, ${ }^{18,19}$ method 2 has potential as a model system for the biomineralization of iron oxides. We note, however, that no green rust intermediates have been observed in the bacterial systems. Interestingly, magnetite formation in the teeth of marine molluscs (chitons) also involves the transformation of ferrihydrite but green rust intermediates have been observed ${ }^{20}$ the subsequent reaction products include both $\mathrm{Fe}_{3} \mathrm{O}_{4}$ and $\alpha$ $\mathrm{FeOOH}$ and the system appears to be chemically similar to the inorganic preparation at 
$\mathrm{pH} 7$ reported in this paper. Furthermore, the chiton $\mathrm{Fe}_{3} \mathrm{O}_{4}$, like the inorganic products described here, does not show the crystallochemical specificity of bacterial magnetite. Thus a future strategy will be to eliminate green rust intermediates from the ferrihydrite to spinel reaction pathway.

Previous workers ${ }^{3,8}$ have proposed that the reaction of $\mathrm{Fe}^{\mathrm{II}}$ with $\mathrm{Fe}^{\mathrm{III}}$ oxides results in $\mathrm{Fe}_{3} \mathrm{O}_{4}$ by a mechanism involving the formation of soluble mixed valence complexes. The rate limiting step appears to be the transformation of green rust and this reaction step is profoundly influenced by the $\mathrm{pH}$, temperature and nature of anionic additives present in the reaction medium. Both $\mathrm{P}_{\mathrm{i}}$ and $\mathrm{SO}_{4}^{2-}$ stabilize the intermediate presumably through surface adsorption, and reduce the rate of spinel formation. At high temperature $\left(100^{\circ} \mathrm{C}\right)$, relatively large concentrations of additive can be tolerated, whereas at room temperature concentrations as low as $1 \mathrm{~mol} \% \mathrm{P}_{\mathrm{i}}$ result in complete inhibition of $\mathrm{Fe}_{3} \mathrm{O}_{4}$ crystallization. The consequent reduction in rate at intermediate additive concentrations results in morphological enhancement of the octahedral habit of spinel crystals grown from partial $\mathrm{Fe}^{\mathrm{II}}$ oxidation at $100^{\circ} \mathrm{C}$. A similar effect is observed with $\mathrm{SO}_{4}^{2-}$ and with a reduction in the $\mathrm{pH}$ to 7 in method 2. Since the (111) octahedral faces of $\mathrm{Fe}_{3} \mathrm{O}_{4}$ are intrinsically stable, the increased resolution in morphology is unlikely to be due to specific surface interactions between these crystal faces and $\mathrm{PO}_{4}^{3-}$ and $\mathrm{SO}_{4}^{2-}$ anions, although $\mathrm{P}$ was detected in the $\mathrm{Fe}_{3} \mathrm{O}_{4}$ crystals analysed by e.d.X analysis. Bacterial magnetites, on the other hand, show a range of species-specific morphologies that have not yet been replicated in inorganic preparations, and this must be a priority of future work since such speciality materials may have important technological application.

This work was supported by SERC grant GR/D30754. R. B.F. was supported by the US National Science Foundation. We thank Dr G. C. Papaefthymiou for help with Mössbauer spectroscopy and discussions.

\section{References}

1 E. Matijevic, Langmuir, 1988, 2, 12.

2 P. S. Sidhu, R. J. Gilkes and A. M. Posner, J. Inorg. Nucl. Chem., 1978, 40, 429.

3 Y. Tamaura, K. Ito and T. Katsura, J. Chem. Soc., Dalton Trans., 1983, 189.

4 T. Sugimoto and E. Matijevic, J. Colloid Interface Sci., 1980, 74, 227.

5 R. M. Taylor and U. Schwertmann, Clay Minerals, 1974, 10, 299.

6 K. Kaneko and T. Katsura, Bull. Chem. Soc. Jpn., 1979, 52, 747.

7 R. M. Taylor, Clays Clay Min., 1984, 32, 167.

8 T. Misawa, K. Hashimoto and S. Shimodaira, Corros. Sci., 1974, 14, 131.

9 S. Mann, A. J. Skarnulis and R. J. P. Williams, J. Chem. Soc., Chem. Commun., 1979, 1067.

10 S. Mann and J. P. Hannington, J. Colloid Interface Sci., 1988, 122, 326.

11 S. B. Couling and S. Mann, J. Chem. Soc., Chem. Commun., 1985, 1713.

I2 S. Mann, Chem. Br., 1987, 23, 137.

13 S. Mann, N. H. C. Sparks and R. P. Blakemore, Proc. R. Soc. London, B, 1987, $231,477$.

14 W. Kündig and R. S. Hargrove, Solid State Commun., 1969, 7, 223.

15 B. Gillot, F. Bouton, J. F. Ferriot, F. Chassagneux and A. Rousset, J. Solid State Chem., 1977, $21,375$.

16 R. L. Parfitt, J. D. Russell and V. C. Farmer, J. Chem. Soc., Faraday Trans. 1, 1976, 72, 1082.

17 J. D. Bernal, D. R. Dasgupta and A. L. Mackay, Clay Min. Bull., 1959, 4, 15.

18 S. Mann, R. B. Frankel and R. P. Blakemore, Nature, 1984 310, 405.

19 R. B. Frankel, G. C. Papaethymiou, R. P. Blakemore and W. O'Brien, Biochim. Biophys. Acta, 1983, 763, 147.

20 K. S. Kim, D. J. Macey, J. Webb and S. Mann, Proc. R. Soc. London, B, 1989, 237, in press. 